\title{
Differences in resource management affects drought vulnerability across the borders between Iraq, Syria, and Turkey
}

\author{
Lina Eklund $^{1}$ and Darcy Thompson ${ }^{1}$
}

\begin{abstract}
Much discussion has taken place exploring a potential connection between the 2007-2009 Fertile Crescent drought and Syria's uprising-turned civil war beginning in 2011. This study takes an integrated perspective on the 2007-2009 drought in the border region of Iraq, Syria, and Turkey by looking at the meteorological, agricultural, and socioeconomic aspects of drought vulnerability. Satellite-based precipitation and vegetation data help outline the drought's spatial and temporal properties. In order to understand the context in which this drought happened, we also look at the trends in vegetation productivity between 2001 and 2015 , as well as each country's different politico-economic factors affecting land and water resource management leading up to the drought. The findings show that, although the drought was severe in Syria, it was not the only country affected, nor necessarily the worst hit meteorologically. The agricultural drought lasted $2 \mathrm{yr}$ in most affected areas on the Iraqi and Syrian sides, however, only 1 yr in the affected areas on the Turkish side. The vegetation trend analysis shows a striking difference between the Syrian and Turkish sides of the border. Turkey experienced a general improvement in land productivity between 2001 and 2015, whereas Iraq and Syria show a generally negative productivity trend. The fact that the decline in rainfall had different effects on crops in each of the three countries highlights the role government and private sector resource management and infrastructure play in reducing drought vulnerability. The findings of this study highlight the need for an integrated approach to research that investigates the interconnection between climate and conflict.
\end{abstract}

Key Words: drought; fertile crescent; land degradation; resource management

\section{INTRODUCTION}

A number of studies have linked the 2011 political protests in Syria and the ensuing civil war to the severe drought that affected the Fertile Crescent region between the years 2007 and 2009 (Femia and Werrell 2012, Azmeh 2014, Kelley et al. 2015). Although this region, which spans parts of Iraq, Syria, and Turkey, is accustomed to climate variability, this drought was reportedly the worst recorded in the region in the last 900 years (Kelley et al. 2015, Cook et al. 2016). Analysts have argued that the socioeconomic impact of the severe drought prompted widespread rural to urban migration, which in turn led to marginalization among migrant groups and political upheaval (Femia and Werrell 2012, Azmeh 2014, Gleick 2014, Kelley et al. 2015). Displacement reports from both the Syrian government and United Nations (UN) assessment missions have been used to establish the link between biophysical drought and migration (United Nations 2009). However, these assessments do not represent a complete picture of the actual effects of the drought on the ground. Iraq and Turkey, two neighboring countries that were also affected by the drought, did not report the same levels of socioeconomic distress in connection to it. These differences between countries in the Fertile Crescent region could suggest differences in both biophysical and socioeconomic vulnerability to drought. To date, no drought assessment measuring vegetation status and its response to the drought has been carried out in the region.

The degree to which climate or environmental change contributes to social or political unrest or conflict is a hotly debated topic at the present time and one with no established consensus (Bernauer et al. 2012, von Uexkull et al. 2016). The field of research consists of studies that explore the relationship between climate and armed conflict, relying on both qualitative and quantitative methodological approaches (Bernauer et al. 2012). These studies, however, present rather contradictory findings. Whereas Burke et al. (2009) found that civil conflict in subSaharan Africa was linked to increased temperatures between the years 1982 and 2002, Buhaug (2010) criticized the study's approach and emphasized the fact that, although temperatures had increased steadily since 2000 , civil conflicts had decreased. Elaborating on the study by Burke et al. (2009), Buhaug (2010) found that alternative models show no relationship between temperature and civil war. Furthermore, von Uexkull et al. (2016) found that drought generally was not linked to civil conflict, but that drought increased the likelihood of sustained conflicts in areas with high dependence on agriculture. The study thus emphasized vulnerability as an important factor and highlighted the need to understand the wider sociopolitical and environmental context in which the drought occurs.

Degradation of land refers to a decline in land productivity that can be attributed to different human activities (United Nations Convention to Combat Desertification (UNCCD) 1994). Semiarid regions are particularly sensitive to land degradation processes as many of these regions worldwide have a long history of human land use (Vicente-Serrano 2015). Furthermore, current climate change processes are considered important factors driving land degradation (Le Houérou 1996). On a global level, however, a majority of semiarid areas showed positive vegetation trends between 1982 and 2011 (Vicente-Serrano et al. 2015). Another satellite-based investigation of land productivity patterns in the Middle East between 1982 and 2000 showed that northern Syria and southern Turkey generally had a positive trend in vegetation productivity, but that land degradation could be identified in parts of northern Iraq (Nielsen and Adriansen 2005). Since that particular study, no investigations about the productivity of land 
on a regional scale have been conducted in the Middle East. Drought refers to a relative decrease in water availability, mostly caused by a reduction in rainfall (Belal et al. 2014). Much research is focused on the meteorological aspects of drought (i.e., reduction in precipitation); however, an agricultural perspective that focuses on soil moisture and crop production can provide more indepth insight into the socioeconomic impacts of drought (Eklund and Seaquist 2015). This can be carried out using satellite images to assess the vegetation quality as an indicator of soil moisture (Gouveia et al. 2009, Karnieli et al. 2010). Drought by itself is not a natural disaster; it becomes one when the lived effects of the drought are extremely detrimental to local populations. This has been referred to as socioeconomic drought (Wilhite and Buchanan-Smith 2005, Eklund and Seaquist 2015). As the most severe drought "in the instrumental record" (Kelley et al. 2015), the 2007-2009 meteorological drought in the Fertile Crescent has caused crop failures in Iraq and Syria, which has led to the erosion of livelihoods in the region (Trigo et al. 2010, UNDP 2010, Kelley et al. 2015). The severity of this drought has been attributed to the long-term drying trend that is an effect of anthropogenic climate change (Kelley et al. 2015, Cook et al. 2016).

This paper investigates the possible impacts that political and socioeconomic factors had on the severity of the 2007-2009 drought as experienced by Iraq, Syria, and Turkey. By mapping precipitation levels, land productivity trends, and vegetation anomalies in this border region, we aim to bring clarity to how the vegetation productivity relates to the management of resources in each of these three countries, which may have influenced the socioeconomic vulnerability to drought, as well as the lived impact of it.

\section{METHODS}

\section{Study area}

The analysis focuses on an area of approximately $330,000 \mathrm{~km}^{2}$, covering the border region between Iraq, Syria, and Turkey (coordinates $36.8^{\circ} \mathrm{E}, 38.2^{\circ} \mathrm{N}$, and $44.2^{\circ} \mathrm{E}, 34.9^{\circ} \mathrm{N}$ ). This includes (parts of) the governorates of Duhok and Ninewa in Iraq, the governorates of Al-Hassakah, Ar-Raqqa, and Aleppo in Syria, and the southeastern Anatolia region in Turkey (Fig. 1).

The study area is located in the Tigris-Euphrates river basin. The Euphrates river is situated in the western part of the study area and runs from Turkey to Syria (Fig. 1). The Tigris river runs along the border between Iraq, Syria, and Turkey in the eastern part of the study area. Precipitation is concentrated between October and April and falls as snow in the elevated areas, which leads to larger river flows during snow melt (Beaumont 1998). There is a strong north-south precipitation gradient in the whole river basin (Beaumont 1996), which means that more precipitation falls on the Turkish side of the study area, than on the Iraqi and Syrian sides. The study area is thus suitable for rainfed dryland farming, and more than half of the cultivated lands in the Al-Hassakah governorate in Syria is rainfed (United States Agency for International Development (USAID). 2014). Similarly, the northeastern parts of Iraq consist of mainly rainfed winter croplands (Eklund et al. 2015). In southeastern Turkey and parts of northeastern Syria, however, irrigated cash crops, such as tobacco, cotton, and pistachio nuts, as well as legumes, are cultivated (Beaumont 1996, Yesilada et al. 2010, Mourad and Berndtsson 2012).
Fig. 1. Study area map showing the different provinces included in the analysis. Land cover data for 2010 come from Globeland30, provided by National Geomatics Center of China. Furthermore, the Mean Annual EVI (MODIS) and the Mean Annual Precipitation (TRMM) are shown.

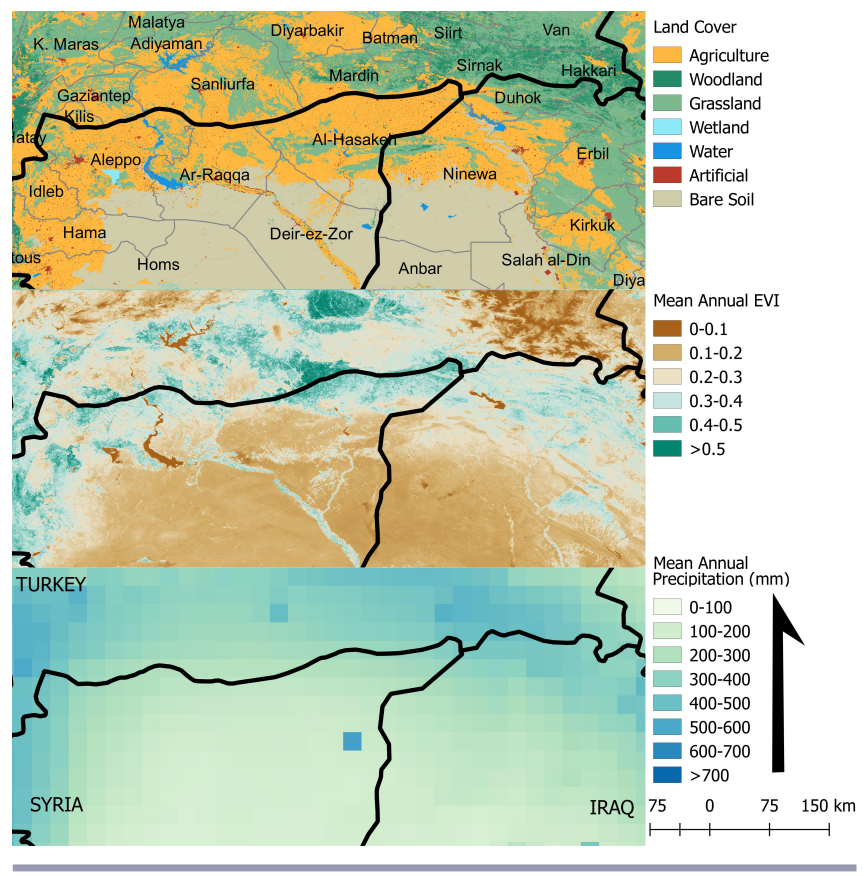

\section{Data and methods}

Satellite data provide opportunities for monitoring the land surface on a continuous basis. Several indices have been developed to enable the monitoring of vegetation cover and health, Normalized Difference Vegetation Index (NDVI) and Enhanced Vegetation Index (EVI) being the most commonly used indices (Solano et al. 2010). These indices are based on the fact that green vegetation has a high reflectance of light in the infrared wavelengths, which is invisible to the human eye. For this study, we used the MODerate Imaging Spectroradiometer (MODIS)'s EVI (the MOD13Q1 product, collection 5), which provides a measure of the greenness of the vegetation as an indicator of water availability in the soil. The data have a spatial resolution of $250 \mathrm{~m}$ and a temporal resolution of $16 \mathrm{~d}$. The EVI uses the difference between near infrared and red reflectances to detect vegetation greenness, but it also uses the difference between blue and red reflectance to account for atmospheric disturbance (Eq. 1) (Solano et al. 2010).

$$
E V I=G \times \frac{\rho_{\text {NIR }}-\rho_{\text {red }}}{\rho_{\text {NIR }}+C_{1} \times \rho_{\text {red }}-C_{2} \times \rho_{\text {blue }}+L}
$$

Where $\mathrm{G}=2.5$ (gain), $\rho$ NIR = near infrared reflectance, $\rho$ red $=$ red reflectance, $\mathrm{Cl}=6$ (red band coefficient for aerosol resistance), $\mathrm{C} 2=7.5$ (blue band coefficient for aerosol resistance), and $\mathrm{L}=1$ (canopy background factor). This yields a unitless value between 0 and 1 , where 0 means no vegetation, and 1 describes very dense 
vegetation. The median EVI value in April in this region is slightly less than 0.3 , and the maximum is around 0.35 (Eklund and Seaquist 2015).

Trend analysis of vegetation is commonly used to assess land degradation or changes in vegetation productivity (de Jong et al. 2011, Brandt et al. 2016). Usually, trends are established using linear regression at annual (Bai et al. 2008) or seasonal intervals (Eklundh and Olsson 2003). To estimate the average amount of vegetation change per year, we used the Theil-Sen slope, which calculates the median of all slope estimates between all potential pairs of points (Hoaglin et al. 1983, Fensholt and Proud 2012). The Theil-Sen slope is a nonparametric test especially suitable for time series of vegetation indices, as they often do not meet parametric assumptions of normality and heteroscedasticity (Hoaglin et al. 1983, Alcaraz-Segura et al. 2010, Fensholt and Proud 2012, Brandt et al. 2016). Furthermore, the Theil-Sen procedure is especially suitable for short or noisy time series due to its robustness against outliers. Vegetation peak values (maximum of March-May) of EVI were calculated and used in a pixel-wise calculation of the Theil-Sen slope between 2001 and 2015 on a yearly basis. Areas with $p<0.05$ were masked to show only the statistically significant trends at a $95 \%$ confidence level.

Globeland 30 (provided by National Geomatics Center of China; Chen et al. (2015)) is a $30 \mathrm{~m}$ resolution, global, open-access land cover classification product consisting of 10 land cover types. The classification is based on data from different sources for the year 2010 (+/- 1 year), including satellite images, regional and national land cover maps, MODIS vegetation data, and global elevation data. The Tropical Rainfall Measuring Mission (TRMM, v. 3B42) (Huffman et al. 2007) data set has a spatial resolution of $0.25^{\circ}$ and a temporal coverage of 1998-2015. We used summed data of the rainy season (January-April) for the years 2001-2015.

In order to facilitate a combined analysis of land cover, precipitation, and EVI, and to overcome the problem of different spatial resolutions in the data, we generated 1,000 randomly sampled points and overlaid them with land cover data (Globeland 30), precipitation data (TRMM), and EVI data. All points falling within the land cover "agriculture" $(n=467)$ were used to create time series charts of yearly precipitation and EVI for the three countries.

Then the 1,000 random points were used to extract Theil-Sen slope data together with land cover. The points were divided into two groups, points with agricultural land cover $(n=467)$ and points with other land covers $(n=533)$. The number of points located in areas with positive $(>0.005)$, negative $(<-0.005)$, or no (significant) trend according to the Theil-Sen slope were counted to show the share of agricultural lands with positive and negative trends in each country.

Agricultural drought, representing a relative reduction in soil moisture that affects crop production negatively, was measured by calculating yearly EVI anomalies for the vegetation peak months (average of March-May). Anomalies were calculated using the Z-score method, which is a normalization method that allows for comparison over different areas. We calculated EVI Zscores for each year by dividing the difference between the yearly values $(x)$ and the average $(\mu)$ for all years (2001-2015) by the standard deviation $(\sigma)$ for all years (Eq. 2) (Eklund and Seaquist 2015).

$$
z=\frac{x-\mu}{\sigma}
$$

The resulting Z-scores show how many standard deviations the observed value deviates from the normal value.

For meteorological drought assessments, a standard reference period of $30 \mathrm{y}$ is usually required to characterize the normal precipitation conditions. For remote sensing assessments, there are no specific requirements, but the longer the period, the more reliable the average is. In this case, a reference period of $15 \mathrm{y}$ was used based on the available record of MODIS. Reference periods of between 10-15y are not uncommon in satellite-based drought assessments due to the limited availability of longer time series (Singh et al. 2003, Vicente-Serrano 2007, Rhee et al. 2010, Trigo et al. 2010).

The remote sensing analyses of the three countries were coupled with an investigation of the political and socioeconomic contexts in which the drought occurred in each of the three countries leading up to the 2007-2009 period. Literature discussing the economic policies and strategies of the Iraqi, Syrian, and Turkish governments were consulted, as well as literature tracing each country's changing agricultural policies and programs over several years.

\section{RESULTS}

This study's assessment of the 2001-2015 trends in vegetation productivity shows important differences between Iraq, Syria, and Turkey (Figs. 2 and 3). The most striking difference is in the border region between Syria and Turkey in the central part of the study area, where there is an overall positive EVI trend on the Turkish side of the border, and a negative EVI trend on the Syrian side. Furthermore, the Iraqi and Syrian parts of the study area show generally negative trends, whereas Turkey has several areas showing positive trends (Fig. 3). Some areas on the Turkish side, in the western part of the study area, show a negative trend in productivity. These areas are located around, and thus likely fed by, the Euphrates River, whereas the areas showing a positive vegetation development are located around the Tigris River. This implies that there are differences between river basins in terms of their ability to help maintain land productivity. Summarized into positive, negative, and no significant or very small trends, we can see that about $20 \%$ of randomized points located in Syria's agricultural areas had a negative trend, whereas Iraq and Turkey had $1 \%$ and $5 \%$, respectively (Fig. 3). Positive trends were seen in $7 \%$ of Turkey's agricultural areas, but only $1 \%$ of Syria and Iraq, respectively, showed positive trend values. In other land covers, such as grasslands and forest, Syria has fewer negative trend areas, but also no random points with positive trends at all. The findings presented by Nielsen and Adriansen (2005) showed that the Syrian and Turkish parts of the study area had a positive trend between 1982 and 2000. Our analysis thus shows that this trend has been continued in Turkey, but reversed in Syria.

There are different temporal developments in precipitation and vegetation across the three countries (Fig. 4). Whereas Iraq and Syria show an overall negative development in precipitation and vegetation productivity, Turkey's precipitation and vegetation seem fairly stable or even positive. A decline in precipitation for all three countries during the drought year 2008 can be seen in 
Fig. 2. Land productivity trends in the border region between Iraq, Syria, and Turkey 2001-2015, indicated by the Theil-Sen Slope of the Enhanced Vegetation Index (EVI). The values represent the average yearly change in EVI units, which means that a value of -0.01 represents a general decrease by 0.15 EVI units over the 15 -y time period. Not significant areas $(p>0.05)$ have been masked.

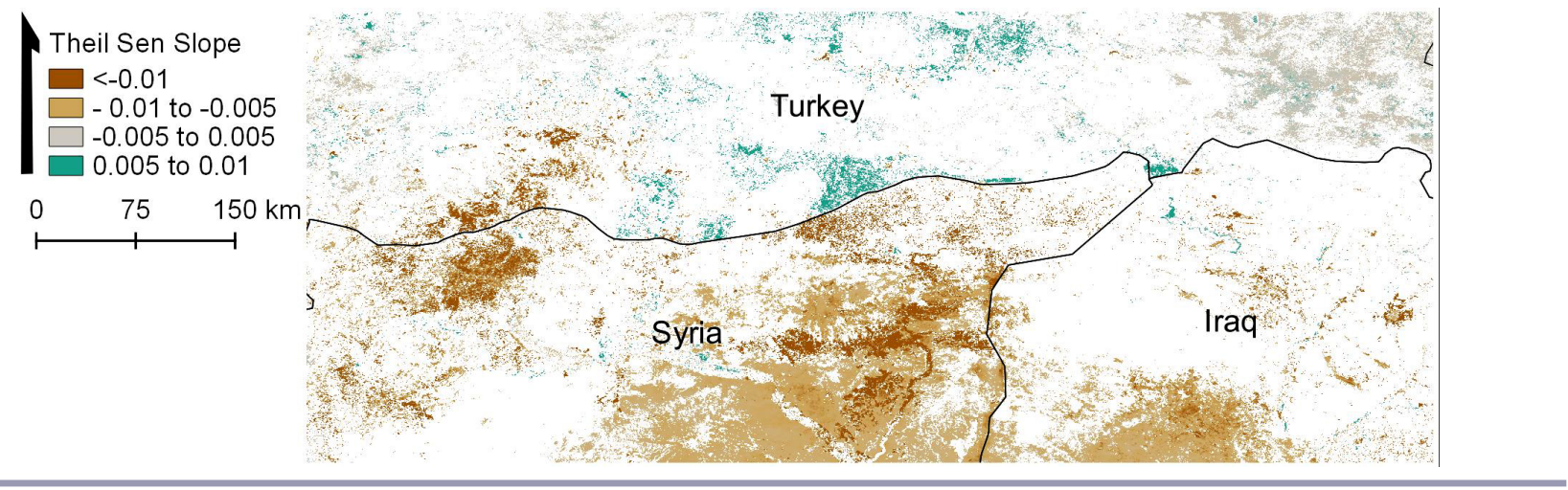

Fig. 3. Share of random points with pixels showing negative, positive, or no trend (total $n=1000)$ in agricultural areas $(n=$ $467)$ and other land covers $(n=533)$.

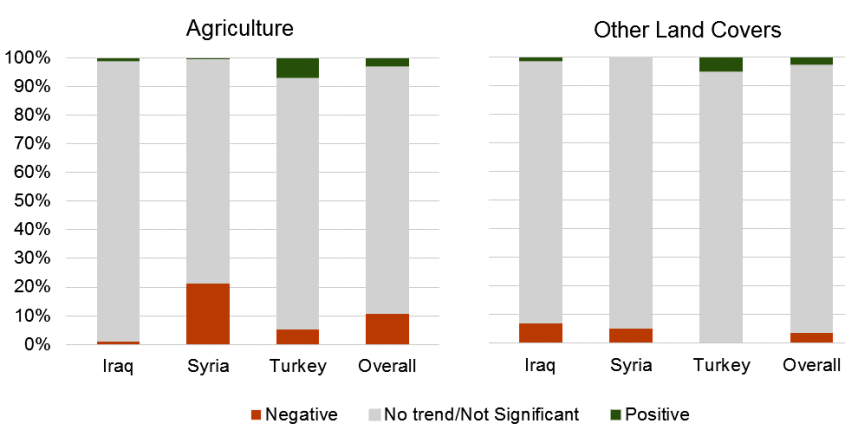

Fig. 4. However, the reported drought year 2007 does not show any clear decline in precipitation. Furthermore, in 2009, only Iraq showed an anomaly in precipitation. Concurrently, the agricultural drought assessment shows a situation of strong negative anomalies in 2008 in a large part of the study area (Fig. 5). Some agricultural areas in Turkey, just north of the Syrian border, show positive anomalies, likely due to heavy irrigation despite drought conditions. In 2009, the drought had eased on the Turkish side of the border, but remained in northwest Iraq and northeast Syria. This brings new insights into how long the drought lasted in the region as it shows that most areas in Iraq and Syria had only weak to moderate negative vegetation anomalies in 2006 and 2007, and a large part of the study area saw positive anomalies in 2010 .

\section{DISCUSSION}

Our assessment shows very small productivity changes in agricultural areas over the last $15 \mathrm{yr}$ on the Iraqi side of the study area (Fig. 3). This can be attributed to a number of economic, political, and social factors that shaped Iraq over the last four decades. Since the 1970s, Iraq has relied heavily on agricultural imports funded by oil revenues to achieve food security (Schnepf
Fig. 4. Time series of January-April precipitation and peak season EVI in agriculture points (total $n=467$ ) in northwest Iraq $n=109)$, northeast Syria $(n=184)$, and southeast Turkey $(n=$ 174).

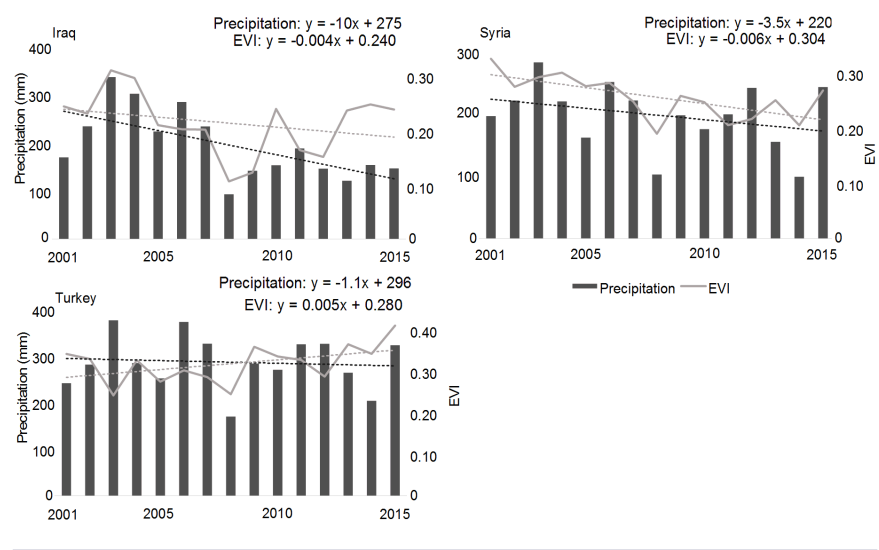

2004). The role of agriculture in the Iraqi economy has decreased as a result of this trend, which has led to a reduction in agricultural infrastructure development. Furthermore, nearly three decades of conflict have diverted the attention of the Iraqi regime from statelevel policy planning and implementation, not least concerning water resources. In 1980, Iraq invaded Iran, which led to a costly 8-yr conflict. During this time, the government of Iraq carried out the "Anfal" campaign against the Kurdish areas in the north, which included the destruction of villages, land, and water sources. People were persecuted, killed, or relocated to urban areas, which in turn caused land abandonment and damaged the agricultural development of this area (Human Rights Watch 1993, Eklund et al. 2015). The Iran-Iraq war was followed by Iraq's invasion of Kuwait in 1990, an event that prompted UN-sanctioned military action and international economic sanctions. Oil exports were cut off, as were food imports, and an extensive bombing campaign strategically damaged key infrastructure, including hydroelectric dams, sewage and water purification systems, electrical grids, and 
Fig. 5. Drought represented by vegetation anomalies 2006-2010 based on EVI for 2001-2015.
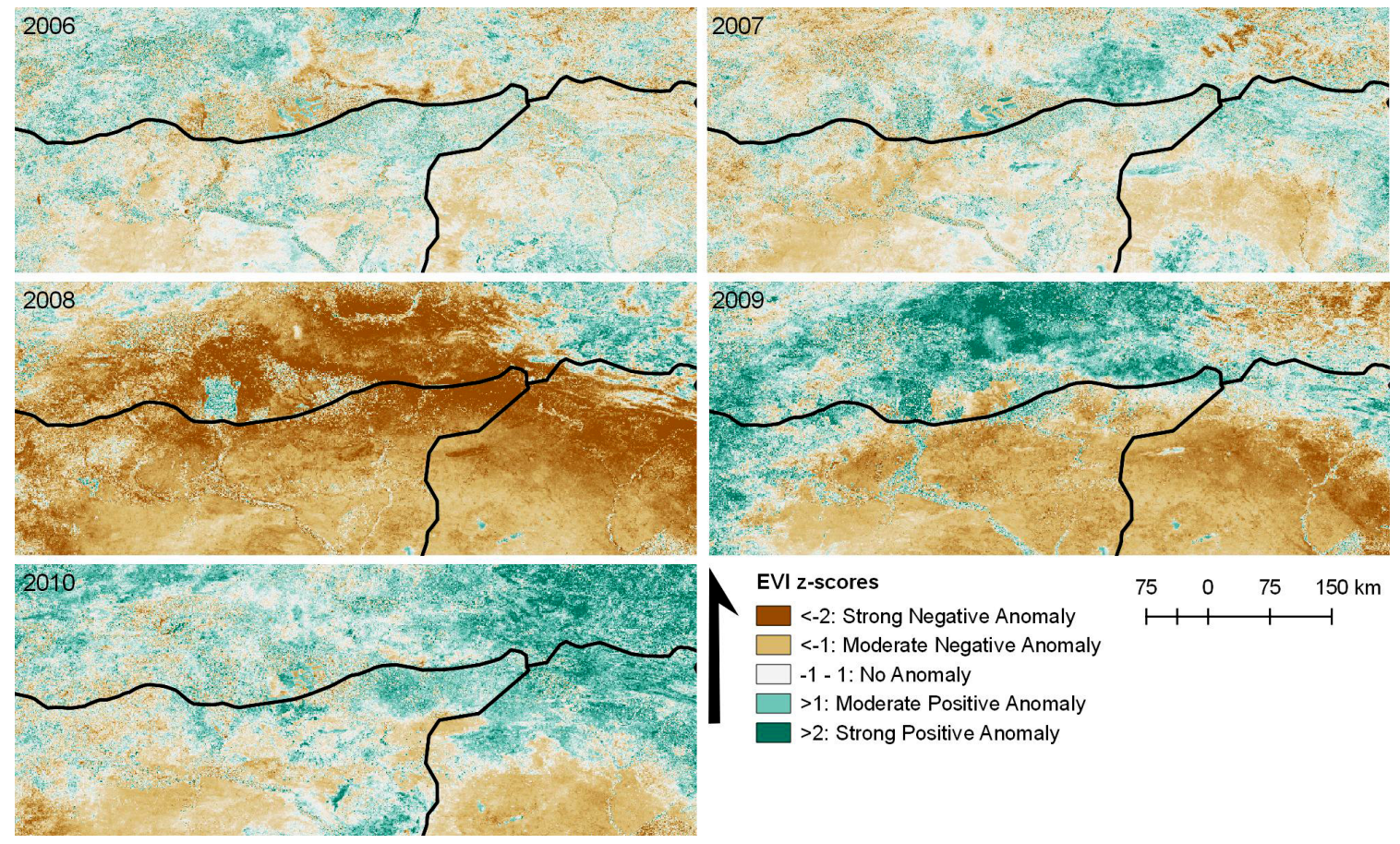

roads (United Nations Environment Programme (UNEP) 2003). In the face of no food imports, the government of Iraq implemented new agricultural policies designed to increase domestic production (Gibson et al. 2012). However, after years of limited investment in irrigation infrastructure, the soil was in poor condition as salinity had degraded much of the older irrigated areas, making them unproductive (USAID 2004). The government's mandate was to expand agricultural lands into previously uncultivated areas using surface and groundwater for irrigation, which strained the country's limited water resources (Gibson et al. 2012). In 1997, food imports were resumed under the Oil-for-Food Program (OFFP), and by 2002, close to $80 \%$ of cereals consumed came from imported grain (Schnepf 2004). Policies to increase food production, however, continued depleting the country's groundwater reservoirs. This precarious water situation was compounded by a major drought in the late 1990s, which lasted several years. By 2003, when Saddam Hussein's government fell, Iraq's land and water resources were in poor condition, and our land productivity assessment shows few improvements. In the aftermath of the 2003 American invasion, the Kurdish region of Iraq experienced significant economic development. Agriculture, however, remained underdeveloped and was reported to have a low relevance in the rural household economies of the Duhok governorate in 2011, with only $20 \%$ of the households drawing incomes from agriculture, which reduced their region's overall vulnerability to drought (Eklund and Pilesjö 2012, Eklund and Seaquist 2015). Iraq thus experienced a meteorological and agricultural drought, but was less affected on a socioeconomic level.

The Syrian side of the study area shows, to a large extent, negative vegetation trends, indicating land degradation in croplands (Figs.
2 and 3) as an effect of the overexploitation of land. Food selfsufficiency has traditionally been the driving force of the Syrian government's agricultural policies (Sarris 2001). Beginning in the late 1990s, however, the government adopted more marketoriented agricultural policies and began supporting the production of strategic crops (Sarris 2001, Varela-Ortega and Sagardoy 2002, Maletta 2003). Irrigated areas were enlarged, especially in the north-east despite evidence showing that water utilization was dangerously above the recommended levels (Maletta 2003). The World Bank concluded that Syria's focus on strategic crop production was leading to overextraction and depletion of available groundwater resources (World Bank 2001). Farmers were relying heavily on dam reservoirs and groundwater reserves, often using unlicensed wells, to irrigate water-intensive crops, such as cotton (Varela-Ortega and Sagardoy 2002, Elhadj 2008). By 2000, almost $60 \%$ of the country's irrigated land was reliant on groundwater resources (United Nations - Economic and Social Commission for Western Asia (UN-ESCWA) 2005). During 1998-1999, a drought-related decrease in groundwater aquifer tables was recorded, as well as increasing salinity, leading to land degradation. When the drought struck in 2006-2007, the situation for groundwater and land resources was already strained, and thus the drought simply "exacerbated an already disastrous situation" (de Châtel 2014). This is supported by our biophysical assessment, showing largely negative vegetation trends since the year 2000. Furthermore, the socioeconomic situation of the northeast region had seen a long-term socioeconomic decline due to government neglect. The region had high poverty and illiteracy rates and a strong reliance on agriculture (Ababsa 2014, de Châtel 2014). In 2008 and 2009, the Syrian government also cancelled several state subsidies, such as reduced fuel and fertilizer prices, which further strained the rural 
population and the agricultural sector (Hinnebusch 2012, de Châtel 2014). As diesel fuel is used to extract groundwater for irrigation, the farmers' ability to mitigate the drought through irrigation was compromised due to these changed policies. Furthermore, the Syrian government had approved a new national drought strategy in 2006, which was not implemented during the drought period (de Châtel 2014). In the case of Syria, several years of land degradation, government neglect of rural areas, and a strong economic dependence on agriculture made northeastern Syria socioeconomically vulnerable to drought.

Unlike most Middle Eastern countries, Turkey enjoys a surplus of water and has long been the biggest exporter of "virtual water" through agricultural trade in the Middle East and North Africa (MENA) region (Antonelli and Tamea 2015). The Turkish government and private actors have used this water surplus to generate power, improve irrigation systems, and increase agricultural output, especially in Central Anatolia and the Aegean Region where the economy is largely agriculturally based (Ünver 2001). Starting in 1977, the government began constructing 22 dams, 19 hydroelectric power plants, and a number of irrigation networks, known as the Southeastern Anatolia Project (GAP). The Euphrates and Tigris rivers were heavily used in this largescale development project, decreasing the flow of water downstream to Iraq and Syria (Carkoglu and Eder 2001). The privatization and subsequent decentralization of Turkey's hydroelectric sector over the course of the 1980s and 1990s led to further water infrastructure developments as private actors constructed and managed dams, water plants, and irrigation systems under the "build-operate-transfer" model introduced by the government (Baskan 2011). A series of water management policies were implemented in the 1990s and 2000s in an ongoing effort to address environmental issues relating, in part, to the country's rapid urbanization and industrialization (Kibaroglu et al. 2009). Turkey's bid for European Union membership in 1999 required that the country align itself with the European Union "Water Framework Directive" (WFD). This led to the expansion and intensification of the government's resource management policies. Development plans included water management provisions aimed at lessening the impact of drought and frequency of water shortages (Kibaroglu and Baskan 2011). The ongoing refinement of Turkey's water management policies, combined with the significant public and private investments made in regulation provisions, meant that at the time of the 20072009 drought, Turkey was considerably better positioned to deal with the impacts of drought than its neighbors Iraq and Syria. Leading up to the drought, agricultural production in southeast Turkey had been increasing (Figs. 2 and 3). The advanced irrigation systems (including dams for storage) meant that crops in the region were less reliant on rainfall for growth and more reliant on groundwater reserves and surface waters. This made the area more vulnerable to hydrological drought (i.e., reduction in water availability in groundwater reserves and surface waters) than meteorological drought (i.e., the direct effect of decreased precipitation). This could explain Turkey's quick drought recovery after 2008, which was not mirrored in Iraq and Syria, as demonstrated in our analysis.

Hydropolitics in the Euphrates and Tigris river basins have played an important role for the availability of water for agricultural use. Turkey is the upstream riparian and controls how much water reaches Iraq and Syria. Various agreements have been developed since the 1920 s to ensure a fair distribution of water resources, including trilateral negotiations that began in the $1960 \mathrm{~s}$ (Dohrmann and Hatem 2014). In 1987, an agreement was reached stipulating that Turkey would allow $500 \mathrm{~m}^{3} / \mathrm{s}$ to flow downstream to Syria and Iraq. This agreement, however, has been violated several times by Turkey, causing significant tensions between the riparian countries over the last several decades. Both Syria and Iraq are dependent on the two rivers for irrigation and hydroelectricity. Syria receives most of its water resources from the Euphrates, whereas the Tigris is of lesser importance (Korkutan 2001). Iraq's position in the river basin is the least favorable among the three countries, as Syria reduces its water flow when Turkey does (Dohrmann and Hatem 2014). The dams constructed by the Syrian and Turkish governments on the Euphrates and Tigris rivers before 2008 caused a major decrease in the flow of the rivers in Iraq, as well as a deterioration in the water quality (Al-Ansari and Knutsson 2011, Al-Ansari 2013, Kamel et al. 2013). Iraq was also negatively affected by the water policies of Iran, which in 2009 was diverting all perennial rivers running toward Iraq (Al-Ansari and Knutsson 2011). The biophysical assessment of this paper clearly shows the benefits of being the upstream riparian, as is the case of Turkey. This paper demonstrates that control of river flow can contribute to a completely different land productivity development on the upstream side of the border, compared with the downstream side of the border. Being upstream, however, is not enough to ensure a positive land development and resilience to drought. Relying on river water for agricultural production requires irrigation infrastructure, including storage and distribution, and thus an economy that allows for such a development. This is the primary difference between Turkey and its downstream neighbors Iraq and Syria.

In summary, several political, socioeconomic, and biophysical factors have played a role in affecting the land systems in the Fertile Crescent area, and thus the vulnerability to meteorological drought. Economic policies and insufficient management practices that overexploit the lands have led to land degradation in Syria, mainly through increased salinity in the soils. The same extent of land degradation was not found on the Iraqi side of the study area, where land has not been exploited to the same extent. Turkey's use of land was more intense than Syria's, but investment on the part of government and private sector meant that irrigation levels, and thus generally productivity levels, could be maintained.

\section{CONCLUSION}

The analysis of land degradation in the Fertile Crescent shows a negative vegetation productivity trend in both Iraq and Syria that precedes the 2007-2009 drought. This means that the drought occurred at a time when land and water resources were already under stress, especially in Syria, which had the most extensive problems with agricultural land degradation. The analysis also shows a stable and, in many areas, positive vegetation productivity trend in Turkey during the same period. As these three areas share similar precipitation patterns, the large difference in vegetation productivity trends and drought-related vegetation anomalies is suggestive of differences in resource management between the three countries. It becomes clear that politico-economic factors helped shape the vulnerability of the three countries to drought. In the absence of well-adapted resource management policies, 
Syria's efforts to achieve food security led to the overexploitation of agricultural lands and water resources, causing land degradation, and lowered groundwater levels in combination with increased fuel prices could not support irrigation, which could have mitigated the effects of meteorological drought. Iraq, on the other hand, has long relied on imports to sustain its food security, and incentives for agricultural development have been small. Thus, Iraqi agriculture faced drought conditions, but low reliance on agriculture had also reduced the socioeconomic vulnerability to drought. As downstream countries, both Iraq and Syria are dependent on water sources that originate in Turkey. Turkey's access to these water resources has allowed for stable land productivity trends and a faster drought recovery compared with the other two countries. This is, in large part, due to government hydrodevelopment over several decades, combined with significant private investment in the country's hydrosector.

It has been widely discussed that the 2007-2009 drought in the Fertile Crescent might have been a catalyst in the Syrian uprising turned civil war. This perspective fits within a growing body of literature that investigates links between climate-related disasters and conflict in different parts of the world (Bernauer et al. 2012, Theisen et al. 2013, Schleussner et al. 2016). In this paper, we highlight the importance of looking at the actual vegetation changes taking place on the ground in connection to the reduction in precipitation during the drought years. When these differences are discussed in relation to the implementation of different resource management strategies by governments or private actors, it becomes clear that the severity of the effects of the drought are the outcome of biophysical as well as political and socioeconomic factors. On a broader level, our study demonstrates that vulnerability to drought can be positively or negatively affected by resource management strategies. Looking only at the severity of the drought in terms of precipitation does not necessarily provide an accurate representation of the "effects" on the ground. When exploring how environmental or climatological factors contribute to armed conflict, factors that influence the impact of drought should also be taken into consideration.

Responses to this article can be read online at: http://www.ecologyandsociety.org/issues/responses. php/9179

\section{Acknowledgments:}

This research was conducted through the Middle East in the Contemporary World (MECW) project funded by the Swedish Research Council. The authors thank Joshka Wessels, Mine Islar, and Martin Brandt for feedback on the manuscript and Hakim Abdi for helpful advice regarding data analysis.

\section{LITERATURE CITED}

Ababsa, M. 2014. The end of a world: drought and agrarian transformation in northeast Syria (2007-2010) Pages 199-222 in R. Hinnebusch and T. Zintl, editors. Syria from reform to revolt: political economy and international relations. Syracuse University Press, Syracuse, New York, USA.
Al-Ansari, N. A. 2013. Management of water resources in Iraq: perspectives and prognoses. Engineering 5(8):667-684. http://dx. doi.org/10.4236/eng.2013.58080

Al-Ansari, N., and S. Knutsson. 2011. Toward prudent management of water resources in Iraq. Journal of Advanced Science and Engineering Research 1 (1):53-67.

Alcaraz-Segura, D., E. Chuvieco, H. E. Epstein, E. S. Kasischke, and A. Trishchenko. 2010. Debating the greening vs. browning of the North American boreal forest: differences between satellite datasets. Global Change Biology 16(2):760-770. http://dx.doi.org/ https://doi.org/10.1111/j.1365-2486.2009.01956.X

Antonelli, M., and S. Tamea. 2015. Food-water security and virtual water trade in the Middle East and North Africa. International Journal of Water Resources Development 31(3):326342. http://dx.doi.org/10.1080/07900627.2015.1030496

Azmeh, S. 2014. The uprising of the marginalised: a socioeconomic perspective of the Syrian uprising. London School of Economics (LSE) Middle East Centre paper series 6, LSE, London, UK. [online] URL: http://www.lse.ac.uk/middleEastCentre/ publications/Paper-Series/UprisingoftheMarginalised.pdf

Bai, Z. G., D. L. Dent, L. Olsson, and M. E. Schaepman. 2008. Proxy global assessment of land degradation. Soil Use and Management 24 (3):223-234. http://dx.doi.org/10.1111/ j.1475-2743.2008.00169.x

Baskan, A. 2011. Liberalization of Turkey's hydroelectricity sector Pages 83-91 in A. Kramer, A. Kibaroglu, and W. Scheumann, editors. Turkey's water policy. Springer, Berlin, Germany. http://dx.doi.org/https://doi.org/10.1007/978-3-642-19636-2_5

Beaumont, P. 1996. Agricultural and environmental changes in the Upper Euphrates catchment of Turkey and Syria and their political and economic implications. Applied Geography 16 (2):137-157. http://dx.doi.org/10.1016/0143-6228(95)00033-X

Beaumont, P. 1998. Restructuring of water usage in the TigrisEuphrates Basin: the impact of modern water management policies. Pages 168-186 in J. Albert, M. Bernhardsson, and R. Kenna, editors. Transformation of Middle Eastern natural environments: legacies and lessons. Bulletin 103. Yale School of Forestry and Environmental Studies, New Haven, Connecticut, USA.

Belal, A.-A., H. El-Ramady, E. Mohamed, and A. Saleh. 2014. Drought risk assessment using remote sensing and GIS techniques. Arabian Journal of Geosciences 7(1):35-53. http://dx. doi.org/10.1007/s12517-012-0707-2

Bernauer, T., T. Böhmelt, and V. Koubi. 2012. Environmental changes and violent conflict. Environmental Research Letters 7 (1):1-8. http://dx.doi.org/10.1088/1748-9326/7/1/015601

Brandt, M., P. Hiernaux, K. Rasmussen, C. Mbow, L. Kergoat, T. Tagesson, Y. Z. Ibrahim, A. Wélé, C. J. Tucker, and R. Fensholt. 2016. Assessing woody vegetation trends in Sahelian drylands using MODIS based seasonal metrics. Remote Sensing of Environment 183:215-225. http://dx.doi.org/10.1016/j.rse.2016.05.027

Buhaug, H. 2010. Climate not to blame for African civil wars. Proceedings of the National Academy of Sciences 107(38):1647716482. http://dx.doi.org/10.1073/pnas. 1005739107 
Burke, M. B., E. Miguel, S. Satyanath, J. A. Dykema, and D. B. Lobell. 2009. Warming increases the risk of civil war in Africa. Proceedings of the National Academy of Sciences 106(49):2067020674. http://dx.doi.org/10.1073/pnas.0907998106

Carkoglu, A., and M. Eder. 2001. Domestic concerns and the water conflict over the Euphrates-Tigris river basin. Middle Eastern Studies 37(1):41-71. http://dx.doi.org/10.1080/714004364

Chen, J., J. Chen, A. Liao, X. Cao, L. Chen, X. Chen, C. He, G. Han, S. Peng, M. Lu, W. Zhang, X. Tong, and J. Mills. 2015. Global land cover mapping at $30 \mathrm{~m}$ resolution: a POK-based operational approach. ISPRS Journal of Photogrammetry and Remote Sensing 103:7-27. http://dx.doi.org/10.1016/j. isprsjprs.2014.09.002

Cook, B. I., K. J. Anchukaitis, R. Touchan, D. M. Meko, and E. R. Cook. 2016. Spatiotemporal drought variability in the Mediterranean over the last 900 years. Journal of Geophysical Research: Atmospheres 121(5):2060-2074. http://dx.doi.org/ https://doi.org/10.1002/2015JD023929

de Châtel, F. 2014. The role of drought and climate change in the Syrian uprising: untangling the triggers of the revolution. Middle Eastern Studies 50(4):521-535. http://dx.doi.org/10.1080/00263206.2013.850076

de Jong, R., S. de Bruin, A. de Wit, M. E. Schaepman, and D. L. Dent. 2011. Analysis of monotonic greening and browning trends from global NDVI time-series. Remote Sensing of Environment 115(2):692-702. http://dx.doi.org/10.1016/j.rse.2010.10.011

Dohrmann, M., and R. M. Hatem. 2014. The impact of hydropolitics on the relations of Turkey, Iraq, and Syria. The Middle East Journal 68(4):567-583. http://dx.doi.org/10.3751/68.4.14

Eklund, L., A. Persson, and P. Pilesjö. 2015. Cropland changes in times of conflict, reconstruction, and economic development in Iraqi Kurdistan. Ambio 45(1):78-88. http://dx.doi.org/10.1007/ $\underline{\mathrm{s} 13280-015-0686-0}$

Eklund, L., and P. Pilesjö. 2012. Migration patterns in Duhok Governorate, Iraq, 2000-2010. Open Geography 5:48-58. http:// dx.doi.org/10.2174/1874923201205010048

Eklund, L., and J. Seaquist. 2015. Meteorological, agricultural and socioeconomic drought in the Duhok Governorate, Iraqi Kurdistan. Natural Hazards 76(1):421-441. http://dx.doi. org/10.1007/s11069-014-1504-X

Eklundh, L., and L. Olsson. 2003. Vegetation index trends for the African Sahel 1982-1999. Geophysical Research Letters 30 (8):1430-1433. http://dx.doi.org/https://doi.org/10.1029/2002GL016772

Elhadj, E. 2008. Dry aquifers in Arab countries and the looming food crisis. Middle East Review of International Affairs 12(4):111.

Femia, F., and C. Werrell. 2012. Syria: climate change, drought, and social unrest. Center for Climate and Security, Washington, D.C., USA. [online] URL: https://climateandsecurity.org/2012/02/29/ syria-climate-change-drought-and-social-unrest/

Fensholt, R., and S. R. Proud. 2012. Evaluation of earth observation based global long term vegetation trendscomparing GIMMS and MODIS global NDVI time series.
Remote Sensing of Environment 119:131-147. http://dx.doi. org/10.1016/j.rse.2011.12.015

Gibson, G. R., J. B. Campbell, and R. H. Wynne. 2012. Three decades of war and food insecurity in Iraq. Photogrammetric Engineering and Remote Sensing 78(8):885-895. http://dx.doi. org/10.14358/PERS.78.8.895

Gleick, P. H. 2014. Water, drought, climate change, and conflict in Syria. Weather, Climate, and Society 6(3):331-340. http://dx. doi.org/10.1175/WCAS-D-13-00059.1

Gouveia, C., R. M. Trigo, and C. C. DaCamara. 2009. Drought and vegetation stress monitoring in Portugal using satellite data. Natural Hazards and Earth Systems Sciences 9(1):185-195. http:// dx.doi.org/10.5194/nhess-9-185-2009

Hinnebusch, R. 2012. Syria: from 'authoritarian upgrading' to revolution? International Affairs 88(1):95-113. http://dx.doi.org/ https://doi.org/10.1111/j.1468-2346.2012.01059.x

Hoaglin, D. C., F. Mosteller, and J. W. Tukey. 1983. Understanding robust and exploratory data analysis. Wiley, New York, New York, USA.

Huffman, G. J., D. T. Bolvin, E. J. Nelkin, D. B. Wolff, R. F. Adler, G. Gu, Y. Hong, K. P. Bowman, and E. F. Stocker. 2007. The TRMM multisatellite precipitation analysis (TMPA): quasiglobal, multiyear, combined-sensor precipitation estimates at fine scales. Journal of Hydrometeorology 8(1):38-55 http://dx.doi. org/10.1175/JHM560.1

Human Rights Watch. 1993. Genocide in Iraq-the Anfal campaign against the Kurds. Human Rights Watch, New York, New York, USA. [online] URL: http://www.hrw.org/ reports/1993/iraqanfal/ANFAL.htm

Kamel, A. H., S. O. Sulaiman, and A. S. Mustaffa. 2013. Study of the effects of water level depression in Euphrates River on the water quality. Journal of Civil Engineering and Architecture 7 (2):238-247. [online] URL: http://www.davidpublisher.org/ Public/uploads/Contribute/555309bcbd786.pdf

Karnieli, A., N. Agam, R. T. Pinker, M. Anderson, M. L. Imhoff, G. G. Gutman, N. Panov, and A. Goldberg. 2010. Use of NDVI and land surface temperature for drought assessment: merits and limitations. Journal of Climate 23(3):618-633. http://dx.doi. org/10.1175/2009JCLI2900.1

Kelley, C. P., S. Mohtadi, M. A. Cane, R. Seager, and Y. Kushnir. 2015. Climate change in the Fertile Crescent and implications of the recent Syrian drought. Proceedings of the National Academy of Sciences 112(11):3241-3246. http://dx.doi.org/10.1073/ pnas. 1421533112

Kibaroglu, A., and A. Baskan. 2011. Turkey's water policy framework. Pages 3-25 in A. Kramer, A. Kibaroglu, and W. Scheumann, editors. Turkey's water policy: national frameworks and international cooperation. Springer, Berlin, Heidelberg, Germany. http://dx.doi.org/10.1007/978-3-642-19636-2 1

Kibaroglu, A., A. Baskan, and S. Alp. 2009. Neo-liberal transitions in hydropower and irrigation water management in Turkey: main actors and opposition groups. Pages 287-304 in D. Huitema and S. Meijerink, editors. Water policy entrepreneurs. A research companion to water transitions around the globe. Edward Elgar Publishing, Cheltenham, UK. 
Korkutan, S. 2001. The sources of conflict in the Euphrates-Tigris Basin and its strategic consequences in the Middle East. Thesis, Naval Postgraduate School, Monterey, California, USA. [online] URL: http://www.dtic.mil/dtic/tr/fulltext/u2/a401450.pdf.

Le Houérou, H. N. 1996. Climate change, drought and desertification. Journal of Arid Environments 34(2):133-185. http://dx.doi.org/10.1006/jare.1996.0099

Maletta, H. 2003. Private investment in Syrian agriculture and agribusiness. Chapter 3 in C. Fiorillo and J. Vercueil, technical editors. Syrian agriculture at the crossroads. Food and Agriculture Organization (FAO) Agricultural Policy and Economic Development Series 8. FAO, Rome, Italy. [online] URL: http:// www.fao.org/docrep/006/y4890e/y4890e07.htm

Mourad, K. A., and R. Berndtsson. 2012. Analysis of agricultural production in Syria from a virtual water flow perspective. Journal of Agricultural Science and Applications 1(3):60-66.

Nielsen, T. T., and H. K. Adriansen. 2005. Government policies and land degradation in the Middle East. Land Degradation and Development 16(2):151-161. http://dx.doi.org/10.1002/1dr.677

Rhee, J., J. Im, and G. J. Carbone. 2010. Monitoring agricultural drought for arid and humid regions using multi-sensor remote sensing data. Remote Sensing of Environment 114(12):2875-2887. http://dx.doi.org/10.1016/j.rse.2010.07.005

Sarris, A. 2001. Final report on agricultural development strategy for Syria. Food and Agriculture Organization and Government of Italy, Rome, Italy. [online] URL: ftp://ftp.fao.org/country/ syria/pdf/sarris_development_strategy_syria.pdf

Schleussner, C.-F., J. F. Donges, R. V. Donner, and H. J. Schellnhuber. 2016. Armed-conflict risks enhanced by climaterelated disasters in ethnically fractionalized countries. Proceedings of the National Academy of Sciences 113(33):92169221. http://dx.doi.org/10.1073/pnas.1601611113

Schnepf, R. 2004. Iraq agriculture and food supply: background and issues. Policy Archive, Congressional Research Service, Library of Congress, Washington, D.C., USA. [online] URL: http://www.policyarchive.org/handle/10207/1847

Singh, R. P., S. Roy, and F. Kogan. 2003. Vegetation and temperature condition indices from NOAA AVHRR data for drought monitoring over India. International Journal of Remote Sensing 24(22):4393-4402. http://dx.doi.org/10.1080/014311603$\underline{1000084323}$

Solano, R., K. Didan, A. Jacobsson, and A. Huete. 2010. MODIS vegetation index user's guide (MOD13 series). Vegetation Index and Phenology Lab, University of Arizona, Phoenix, Arizona, USA. [online] URL: https://vip.arizona.edu/documents/MODIS/ MODIS VI UsersGuide 01 2012.pdf

Theisen, O. M., N. P. Gleditsch, and H. Buhaug. 2013. Is climate change a driver of armed conflict? Climatic Change 117(3):613625. http://dx.doi.org/https://doi.org/10.1007/s10584-012-0649-4

Trigo, R. M., C. M. Gouveia, and D. Barriopedro. 2010. The intense 2007-2009 drought in the Fertile Crescent: impacts and associated atmospheric circulation. Agricultural and Forest Meteorology 150(9):1245-1257. http://dx.doi.org/https://doi. org/10.1016/j.agrformet.2010.05.006
United Nations (UN). 2009. Syria drought response plan. UN, New York, New York, USA. [online] URL: http://reliefweb.int/ sites/reliefweb.int/files/resources/2A1DC3EA365E87FB8525760F0051E91A-Full_Report.pdf

United Nations Convention to Combat Desertification (UNCCD). 1994. Elaboration of an international convention to combat desertification in countries experiencing serious drought andlor desertification, particularly in Africa. UN-CCD, Bonn, Germany. [online] URL: http://www.unccd.int/Lists/SiteDocumentLibrary/ conventionText/conv-eng.pdf

United Nations Development Programme (UNDP). 2010. Drought - impact assessment, recovery and mitigation framework and regional project design in Kurdistan Region (KR). UNDP, New York, New York, USA. [online] URL: http://www.undp.org/ content/dam/rbas/report/Drought.pdf

United Nations Economic and Social Commission for Western Asia (UN-ESCWA). 2005. ESCWA Water Development Report 1. Vulnerability of the region to socio-economic drought. UNESCWA, Beirut, Lebanon. [online] URL: https://www.unescwa. org/sites/www.unescwa.org/files/publications/files/sdpd-2005-9-a_0. pdf

United Nations Environment Programme (UNEP). 2003. Desk study on the environment in Iraq. UNEP, Geneva, Switzerland. [online] URL: http://postconflict.unep.ch/publications/Iraq_DS. pdf

United States Agency for International Development (USAID). 2004. Agriculture reconstruction and development program for Iraq: irrigation water management assessment and priorities for Iraq. USAID, Washington, D.C., USA. [online] URL: http://pdf. usaid.gov/pdf docs/Pnadi054.pdf

United States Agency for International Development (USAID). 2014. Syrian agriculture: historical and environmental context. USAID, Washington, D.C., USA. [online] URL: http://pdf.usaid. gov/pdf docs/PBAAC901.pdf

Varela-Ortega, C., and J. A. Sagardoy. 2002. Irrigation water policies in Syria: current developments and future options. Chapter 13 in C. Fiorillo and J. Vercueil, technical editors. Syrian agriculture at the crossroads. Food and Agriculture Organization (FAO) Agricultural Policy and Economic Development Series 8. FAO, Rome, Italy. [online] URL: http://www.fao.org/docrep/006/ y4890e/y4890e0u.htm

Vicente-Serrano, S. 2007. Evaluating the impact of drought using remote sensing in a mediterranean, semi-arid region. Natural Hazards 40(1):173-208. http://dx.doi.org/10.1007/s11069-006-0009-7

Vicente-Serrano, S. M., D. Cabello, M. Tomás-Burguera, N. Martín-Hernández, S. Beguería, C. Azorin-Molina, and A. E. Kenawy. 2015. Drought variability and land degradation in semiarid regions: assessment using remote sensing data and drought indices (1982-2011). Remote Sensing 7(4):4391-4423. http://dx.doi.org/https://doi.org/10.3390/rs70404391

von Uexkull, N., M. Croicu, H. Fjelde, and H. Buhaug. 2016. Civil conflict sensitivity to growing-season drought. Proceedings of the National Academy of Sciences 113(44):12391-12396. http:// dx.doi.org/10.1073/pnas. 1607542113 
Wilhite, D. A., and M. Buchanan-Smith. 2005. Drought as hazard: understanding the natural and social context. Pages 329 in D. A. Wilhite, editor. Drought and water crises: science, technology, and management issues. CRC Press, Taylor and Francis Group, Boca Raton, Florida, USA.

World Bank. 2001. Syrian Arab Republic irrigation sector report. World Bank, Washington, D.C., USA. [online] URL: http:// documents.worldbank.org/curated/en/248751468777620327/pdf/ multi0page.pdf

Ünver, İ. O. 2001. Southeastern Turkey: sustainable development and foreign investment. Organisation for Economic Co-operation and Development (OECD) China Conference on Foreign Investment in China's Regional Development, Xi'an, China, OECD, Paris, France. [online] URL: http://www.oecd.org/ investment/investmentfordevelopment/2350280.pdf

Yesilada, A., M. Ucer, and I. Aksoy. 2010. Turkish agriculture sector. Egeli and Company, Istanbul, Turkey. [online] URL: http:// www.epyas.com/Content/Files/Reports/EGCYO_Agriculture_Report. pdf 
Appendix 1. EVI statistics based on a total of 1,000 points located in the study area

\begin{tabular}{|c|c|c|c|c|c|c|c|c|c|c|c|}
\hline & \multicolumn{3}{|c|}{ Iraq } & \multicolumn{4}{|c|}{ Syria } & \multicolumn{4}{|c|}{ Turkey } \\
\hline & Mean EV & I St. Dev. & Min Max & Mean EV & I St. Dev. & Min & Max & Mean EV & I St. Dev. & Min & Max \\
\hline Agriculture & 0.22 & 0.06 & 0.110 .38 & 0.24 & 0.09 & 0.25 & 0.45 & 0.32 & 0.09 & 0.11 & 0.53 \\
\hline Other & 0.17 & 0.08 & $0.08 \quad 0.37$ & 0.12 & 0.05 & -0.02 & 0.37 & 0.19 & 0.08 & -0.03 & 0.45 \\
\hline
\end{tabular}

